\title{
НЕДЕКЛАРИРОВАНИЕ ИЛИ НЕДОСТОВЕРНОЕ ДЕКЛАРИРОВАНИЕ: ОСНОВНЫЕ ОТЛИЧИЯ ПРИ РАЗГРАНИЧЕНИИ СОСТАВОВ АДМИНИСТРАТИВНЫХ ПРАВОНАРУШЕНИЙ
}

\section{NON-DECLARATION OR FALSE \\ DECLARATION: THE MAIN DIFFERENCES IN THE DIFFERENTIATION OF THE COMPOSITION OF ADMINISTRATIVE OFFENSES}

A. Drobotova

Summary. The purpose of this article is the analysis of the qualifying features that make it possible to distinguish between structures of administrative offences that are similar in their object, administrative responsibility for committing quality by Articles 16.2 and 16.4 of the Code of Administrative Offences of the Russian Federation. The relevance of the topic is, first of all, the practice of applying administrative legislation in the field of customs legal relations under customs rules. The author pays special attention to the qualifying elements of administrative offences related to the subject of the offence and the subject of responsibility.

Keywords: administrative offences in the field of customs (violation of customs rules), delimitation of the composition of administrative offenses, grounds for delimiting the composition of administrative offenses, administrative liability, non-declaration or inaccurate declaration of goods, non-declaration or inaccurate declaration of cash by individuals and (or) monetary instruments.

\section{Введение}

H едекларирование или недостоверное декларирование является основанием для привлечения виновного лица к административной ответственности в зависимости от того, какой именно квалифицирующий признак определяет существо правонарушения: это товар или (применимо к физическим лицам) наличные денежные средства и (или) финансовые инструменты.

Проблема разграничения составов административных правонарушений возникла достаточно давно, фактически с того времени, когда субъектам предпринимательской деятельности законом было разрешено участие во внешнеэкономической деятельности, однако судебная практика доказывает необходимость
Дроботова Арина Геннадьевна

Аспирант, Санкт-Петербургский университет технологий управления и экономики, Санкт-Петербург ar.drobotova@gmail.com

Аннотация. Целью данной статьи является анализ квалифицирующих признаков, позволяющих разграничить близкие по своему объекту составы административных правонарушений, административная ответственность за совершение которых предусмотрена статьями 16.2 и 16.4 Кодекса Российской Федерации 06 административных правонарушениях. Актуальность темы исследования определяется, прежде всего, практикой применения административного законодательства в сфере таможенных правоотношений при нарушении таможенных правил. Автор особое внимание обращает на квалифицирующие признаки указанных составов административных правонарушений, относящиеся к предмету правонарушения и субъекту ответственности.

Ключевые слова: административные правонарушения в области таможенного дела (нарушение таможенных правил), разграничение составов административных правонарушений, основания разграничения составов административных правонарушений, административная ответственность, недекларирование либо недостоверное декларирование товаров, недекларирование либо недостоверное декларирование физическими лицами наличных денежных средств и (или) денежных инструментов.

постоянного совершенствования правового инструментария, применимого для правильной квалификации недекларирования или недостоверного декларирования товаров при перемещении их через границу стран - участниц Таможенного союза.

О растущей актуальности исследования рассматриваемой темы свидетельствует также и неослабевающий интерес отечественных авторов, предметом научной деятельности которых являются вопросы административной ответственности. Однако, в основном, предметом исследования становится анализ судебной практики применения норм законодательства об административных правонарушениях, а проблемы квалификации смежных составов правонарушений рассматриваются в рамках изучения частных вопросов, что само 
по себе определяет необходимость обращения внимания к указанной проблеме.

Анализируя содержание статьи 16.2 Кодекса Российской Федерации об административных правонарушениях (далее: КоАП РФ) и основания разграничения составов административных правонарушений, включенных в указанную статью закона, отечественные исследователи обращают внимание на квалифицирующие признаки правонарушений, ответственность за совершение которых установлена нормами ч.ч. 1, и 3 ст. 16.2 КоАП РФ, характерные для определенных элементов составов административных правонарушений, чаще обращая внимание на проблему разграничения составов административных правонарушений, ответственность за совершение которых устанавливается нормами ч.ч. 1 и 2 КоАП РФ.

Так, например, Е.И. Сидоров указывает, что для указанных и смежных с ними (по объекты) составов административных правонарушений объективная сторона характеризуется бездействием, хотя и в отношении ч.ч. 2 и 3 ст. 16.2 КоАП РФ объективная сторона может характеризоваться и активными целенаправленными действиями, а также использованием недействительных документов. Субъективная сторона правонарушений, ответственность за совершение которых предусмотрена ст. 16.2 КоАП РФ, по мнению указанного автора, характеризуется как неосторожностью, так и умыслом, а дополнительным квалифицирующим признаком могут быть цель, мотив совершения правонарушения, либо отсутствие такового [7, с. 63].

Л.Б. Монтян и Н.Н. Пугачева важнейшим квалифицирующим признаком при разграничении составов административных правонарушений, объединенных законодателем в ст. 16.2 КоАП РФ, называют отсутствие (наличие) причиненного ущерба, что позволяет, по мнению указанных исследователей, разграничить составы правонарушений, предусмотренные ч. 1 и ч.ч. 2 и 3 ст. 16.2 КоАП РФ, при этом в первом случае ущерб отсутствует [3, с. 8].

В судебной практике сложилось несколько иное представление о разграничении составов административных правонарушений, объединенных в ст. 16.2 КоАП РФ. Нормами п. 30 Постановления Пленума Верховного Суда РФ от 24.10.2006 г. № 18 «О некоторых вопросах, возникающих у судов при применении Особенной части Кодекса Российской Федерации об административных правонарушениях» [5], действующего в настоящее время в редакции от 25.06.2019 г., в качестве важнейшего квалифицирующего признака, позволяющего разграничить составы административных правонарушений, ответственность за совершение которых пред- усмотрена ч.ч. 1 и 2 ст. 16.2 КоАП РФ называются качественный и количественный критерии.

Если устанавливается количественный критерий, то есть фиксируется факт недекларирования товаров, перемещаемых через таможенную границу, то ответственность возникает по ч. 1 ст. 16.2 КоАП РФ. При этом внимание обращается на то, что недекларирование может выражаться в декларировании только одного вида товаров, перемещаемых через таможенную границу, в декларировании только части товара, либо в предоставлении к таможенному оформлению товара, обладающего иными свойствами, нежели тот, который действительно перемещается через таможенную границу.

В том же случае, если квалифицирующим признаком становится качественный критерий, то есть при условии декларирования всего объема товара декларант или таможенный брокер указывают иные качественные характеристики товара, необходимые для таможенных целей, то ответственность возникает по ч. 2 ст. 16.2 КоАП РФ при условии, что такие сведения послужили основанием для освобождения от уплаты таможенных пошлин, налогов или для занижения их размера.

На необходимость учета позиции Верховного Суда РФ при разграничении составов административных правонарушений по ч.ч. 1 и 2 ст. 16.2 КоАП РФ указывают многие отечественные авторы, в качестве примера можно привести позицию Е.А. Наховой [4, с. 236], Ю.Г. Гвоздева [1, с. 37].

Означенную выше позицию Верховного Суда РФ, полагаем, следует считать чрезмерно упрощенной, поскольку при квалификации административных правонарушений, ответственность за совершение которых предусмотрена нормами ч.ч. 1 и 2 ст. 16.2 КоАП РФ, требуется анализ всех элементов состава правонарушений, а в этом отношении Пленум Верховного Суда РФ рекомендаций не дает.

В Постановлении Пленума ВАС РФ от 08.11.2013 г. № 79 «О некоторых вопросах применения таможенного законодательства» [6] (п. 11) указывается, что административная ответственность наступает в случае, если заявленные недостоверные, в том числе неполные, сведения послужили или могли послужить основанием для освобождения от уплаты таможенных пошлин, налогов или для занижения их размера, неприменения установленных запретов и ограничений, но не дается рекомендаций судам по проблеме разграничения этих составов административных правонарушений.

В связи с отсутствием рекомендаций органов судебной власти по разграничению составов администра- 
тивных правонарушений, ответственность за совершение которых предусмотрена ч.ч. 2 и 3 ст. 16.2 КоАП РФ, данный пробел пытаются восполнить посредством теоретических изысканий. Так, Д.Р. Канищев предлагает в качестве основного критерия разграничения считать характер наступивших или предполагаемых негативных последствий правонарушения. В отношении ч. 1 ст. 16.2 КоАП РФ в качестве такового должно выступать освобождение от уплаты таможенных пошлин, налогов или для занижения их размера, а относительно ч. 3 ст. 16.2 КоАП РФ - несоблюдение (нарушение) запретов и ограничений, установленных законодательством государств - членов Таможенного союза [2, с. 81]. На данное основание для разграничения составов административных правонарушений по ч.ч. 2 и 3 ст. 16.2 КоАП РФ обращает внимание и Е.И. Сидоров [7, с. 64].

Д.В. Чермянинов и А.Э. Курмаев полагают, что квалифицирующим признаком, позволяющим отграничить состав административного правонарушения, предусмотренного ч. 3 ст. 16.2 КоАП РФ, является предоставление декларантом документов, которые обладают свойствами, позволяющими впоследствии говорить об их недействительности (поддельные, полученные незаконным путем, содержащие недостоверные сведения, относящиеся к другим товарам и (или) транспортным средствам и т.д.) [8, с. 142-143].

Таким образом, высший орган судебной власти рекомендует судам при рассмотрении дел о привлечении виновных лиц к административной ответственности за правонарушения, признаки которых определены нормами ч.ч. 1 и 2 ст. 16.2 КоАП РФ, руководствоваться качественным и количественным критериями относительно действий (бездействия) виновного лица. При этом в рассматриваемом Постановлении Пленума Верховного Суда РФ отсутствуют рекомендации судам по квалификации правонарушений по ч. 3 ст. 16.2 КоАП РФ и ст. 16.4 КоАП РФ. Относительно ст. 16.4 КоАП РФ позиция высшего органа судебной власти понятна, поскольку речь идет об определенном субъекте правонарушения (физическое лицо) и предмете (наличные деньги и (или) финансовые инструменты. Однако в отношении квалификации правонарушения, ответственность за совершение которого предусмотрена ч. 3 ст. 16.2 КоАП РФ, требуется более четкая позиция Верховного Суда.

Лингвистический анализ терминов «недекларирование» и «недостоверное декларирование» может также использоваться в качестве основания для разграничения составов административных правонарушений, объединенных в ст. 16.2 КоАП РФ, поскольку наличие приставки «не» в термине «недекларирование» уже предполагает наказуемое бездействие, а недостовер- ность свидетельствует о предоставлении таможенному органу информации, не соответствующей действительным характеристикам перемещаемого через таможенную границу товара.

Для юридической квалификации определенного состава административного правонарушения, составы которых определены в нормах ст. 16.2 КоАП РФ, необходимо учитывать не только позицию высших органов судебной власти, но и квалифицирующие признаки отдельных элементов состава административного правонарушения, а также саму сущность виновных действий (бездействия), устанавливаемую при анализе объективной стороны правонарушения.

\section{Зак^ючение}

При разграничении составов административных правонарушений, объединенных в ст. 16.2 КоАП РФ, необходимо учитывать целый ряд существенных отличий, которые находят отражение как в отдельных элементах составов административных правонарушений, так и в обобщениях судебной практики.

Для цели привлечения виновного лица к административной ответственности по ч. 1 или ч. 2 ст. 16.2 КоАП РФ необходимо, прежде всего, учитывать качественный и количественный критерии, на которые обращает внимание Верховный Суд РФ. Однако учета исключительно этих критериев явно недостаточно для правильной квалификации правонарушения, в связи с чем, полагаем судам дополнительно необходимо учитывать квалифицирующие признаки, характеризующие объективную и субъективную стороны состава административного правонарушения.

Отсутствие или наличие ущерба также следует считать признаком, отличающим составы административных правонарушений, ответственность за совершение которых предусмотрена соответственно частями 1 и 2 ст. 16.2 КоАП РФ.

Отличительным признаком, позволяющим отграничить составы административных правонарушений, ответственность за совершение которых предусмотрена ч.ч. 2 и 3 ст. 16.2 КоАП РФ, следует считать специфику недействительности документов, предоставляемых при пересечении товаров таможенной границы государств - членов Таможенного союза, поскольку в первом случае ответственность возникает при предоставлении недостоверных сведений об их классификационном коде по единой Товарной номенклатуре внешнеэкономической деятельности Евразийского экономического союза, а во втором - за предоставление документов, обладающими признаком недействительности. 


\section{ЛИТЕРАТУРА}

1. Гвоздев Ю.Г. Вопросы административной ответственности при таможенном декларировании товаров // Судья. — 2018. — № 9.—C. 35-39.

2. Канищев Д.Р. Актуальные вопросы привлечения к административной ответственности лиц за недостоверное декларирование товаров, перемещаемых через таможенную границу Таможенного союза, по части 2 статьи 16.2 Кодекса Российской Федерации об административных правонарушениях // Право и экономика. — 2013.— № 6. - С. 72-81.

3. Мунтян Л.Б., Пугачева Н.Н. Практика рассмотрения дел, связанных с применением статьи 16.2 Кодекса Российской Федерации об административных правонарушениях, с участием таможенных органов // Информационно-аналитический журнал «Арбитражные споры» — 2016. - № 2. - С. 5-37.

4. Нахова Е.А. Особенности доказывания и доказательств по некоторым спорам, вытекающим из нарушений таможенного законодательства // Ленинградский юридический журнал. - 2018. - № 3.- С. 236-242.

5. Постановление Пленума Верховного Суда РФ от 24.10.2006 г. № 18 (ред. от 25.06.2019 г.) «0 некоторых вопросах, возникающих у судов при применении Особенной части Кодекса Российской Федерации об административных правонарушениях» // Бюллетень Верховного Суда РФ. 一 2006. - № 12.

6. Постановление Пленума ВАС РФ от 08.11.2013 г. № 79 (ред. от 12.05.2016 г.) «0 некоторых вопросах применения таможенного законодательства» // Вестник ВАС РФ. - 2014. 一 № 1.

7. Сидоров Е.И. Проблемы квалификации административных правонарушений, связанных с недекларированием либо недостоверным декларированием товаров в условиях функционирования Таможенного союза в рамках ЕАЭС // Административное и муниципальное право.— 2016. — № 1.— C. 60-65.

8. Чермянинов Д.В., Курмаев А.Э. 0 вопросах производства по делам 06 административных правонарушениях в области таможенного дела // Российский юридический журнал. - 2016. - № 4.- - С. 139-145.

(c) Дроботова Арина Геннадьевна ( ar.drobotova@gmail.com ).

Журнал «Современная наука: актуальные проблемы теории и практики»

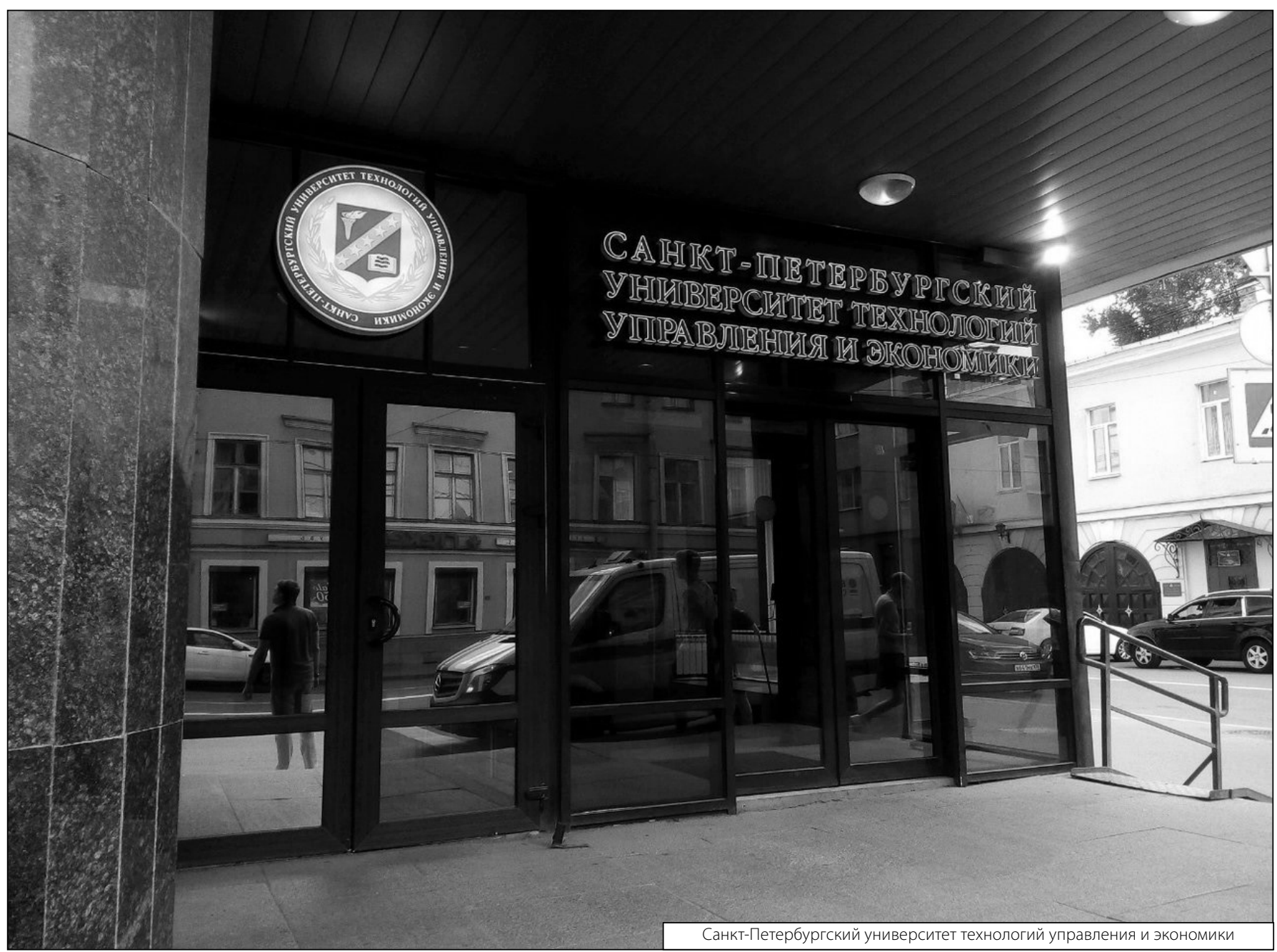

